Party identification and the economy in Europe:

A literature review

Adriaan Luyten and Christophe Crombez

DEPARTMENT OF MANAGERIAL ECONOMICS, STRATEGY AND INNOVATION (MSI) 


\title{
Party Identification and the Economy in Europe: A Literature Review
}

\section{Adriaan Luyten ${ }^{1}$ and Christophe Crombez ${ }^{2}$}

\begin{abstract}
As one of the strongest determinants of the vote choice of United States citizens, party identification has been the object of extensive scholarly attention. Despite fifty years of research, its place in the funnel of causality and its applicability outside the United States remains unclear. In this literature review, we discuss the most influential articles about these two unsolved questions. Furthermore, we evaluate whether propensity-to-vote data can enrich our understanding of European partisanship and its relationship with citizens' evaluation of the economy.
\end{abstract}

Key words: party identification, economic conditions, voting behavior, propensity to vote JEL No. D72, D78

\footnotetext{
${ }^{1}$ Adriaan Luyten is a doctoral candidate at KU Leuven. Address: KU Leuven, Faculty of Business and Economics, Naamsestraat 69, 3000 Leuven, Belgium; Email: Adriaan.Luyten@kuleuven.be.

${ }^{2}$ Christophe Crombez is Professor of Political Economy at KU Leuven and Visiting Professor at Stanford University.
} 


\section{Introduction}

Long before Campbell, Converse, Stokes and Miller wrote their classical book "The American Voter" (1960), party identification (ID) caught the attention of politicians and philosophers. At first, it was considered an irrational force, an obstacle to the proper functioning of democracy. Many political philosophers thought that a democracy could only work effectively if people voted after deliberately and independently assessing the candidates. This is illustrated in the following quotes from George Washington and David Hume.

Let me now take a more comprehensive view, and warn you in the most solemn manner against the baneful effects of the spirit of party... This spirit, unfortunately, is inseparable from our nature, having its root in the strongest passions of the human mind. It exists under different shapes in all governments, more or less stifled, controlled, or repressed; but in those of the popular form it is seen in its greatest rankness and is truly their worst enemy....

It serves always to distract the public councils and enfeeble the public administration. It agitates the community with ill-founded jealousies and false alarms; kindles the animosity of one part against another; foments occasionally riot and insurrection. It opens the door to foreign influence and corruption, which find a facilitated access to the government itself through the channels of party passion.

(George Washington, Farewell Address)

I have mentioned parties from affection as a kind of real parties, beside those from interest and principle. By parties from affection, I understand those which are founded on the different attachments of men towards particular families and persons, whom they desire to rule over them. These factions are often very violent; though, I must own, it may seem unaccountable, that men should attach themselves so strongly to persons, with whom they are no wise acquainted, whom perhaps they never saw, and from whom they never received, nor can ever hope for any favor. 
Yet this we often find to be the case, and even with men, who, on other occasions, discover no great generosity of spirit, nor are found to be easily transported by friendship beyond their own interest. We are apt to think the relation between us and our sovereign very close and intimate. The splendor of majesty and power bestows an importance on the fortunes even of a single person. And when a man's good-nature does not give him this imaginary interest, his ill-nature will, from spite and opposition to persons whose sentiments are different from his own.

(David Hume, "Of Parties in General”, I.VIII.15)

However, as democracies grew more mature, it became clear party ID is a prerequisite for the well-functioning of democracy rather than an obstacle to it. By now, a vast literature demonstrates the importance of party attachments as a central element of democratic politics (Budge et al., 1976; Dalton and Wattenberg, 2000; Dalton and Weldon, 2007; Holmberg, 1994; Miller, 1991). Partisanship enables citizens to orient themselves in politics, it serves as a heuristic to process new information and integrate it in a political belief system. Furthermore, it encourages people to vote and stimulates political participation in general.

In this paper, we present an overview of the literature on party ID. In the second section, we present a summary of the most important papers on the nature of partisanship. Our starting point is the seminal work of Campbell et al. (1960). Their book "The American Voter" instigated a scientific discussion on the importance of party ID in the comprehension of modern politics. The key question raised in these papers relates to the place of party ID in the "funnel of causality", a metaphor used by Campbell et al. (1960), in which proximate influences on voting behavior were themselves subject to explanation, at least in principle, in terms of temporally and causally prior forces. Some scholars (Campbell et al. (1960), Miller (1991), Miller and Shanks (1996), Green and Palmquist (1994)) uphold the view that party ID is an "unmoved mover", i.e. a variable that helps explain political attitudes and behavior, but cannot itself be explained by them. Others (Jackson (1975), Page and Jones (1979), Marcus and Converse (1979), Fiorina (1981), Franklin and Jackson (1983)) contest this view, arguing that there is at least some reciprocal causation between party ID and other political variables. 
In the third section of this paper, we will focus on a particularly interesting observation in this literature: the observed correlation between party ID and evaluations of the economy. Apparently, partisans evaluate the economy more positively when their party is holding office, and more negatively if the government is controlled by an opposing party. Many scholars have been intrigued by this longstanding observation, and have come up with several plausible explanations why this correlation between partisan attachments and economic assessments may occur. We will discuss five different explanations, and assess the strength of the evidence provided in the literature.

The fourth section deals with the complications that arise when one wants to transpose the American concept of party ID to European multiparty systems.

The fifth section discusses an operationalization of party ID that might help to overcome some of these problems. This operationalization is based on propensity-to-vote (PTV) data, and allows for multiple, as well as positive and negative party identifications.

The sixth section presents conclusions. In addition to presenting an overview of the literature the main contribution of this paper is twofold. First of all, we provide an outline of the complications that arise if one wants to assess the impact of economic variables on party ID in Europe. Second, we assess the potential of probability-to-vote data to overcome these complications, and suggest some possibilities for future research.

\section{Party ID}

The concept of party ID was first introduced by Campbell, et al. in their 1960 book "The American Voter". Their work instigated a revolution in political science. As all good scientific 
breakthroughs, the idea put forward by the Michigan Four was simple. Party ID was the attitude that "characterized the individual's affective orientation to an important group-object in his environment". The authors were convinced that the concept they invented was more than just another variable that could enrich models of political behavior. They suggested that it was the most fundamental trait of political behavior ever discussed: "Evidently no single datum can tell us more about the attitude and the behavior of the individual as presidential elector than his location on a dimension of psychological identification extending between the two great parties" (Campbell et al. 1960, p.142).

In the seminal work of the "Michigan Four", party ID is a psychological identification, derived from reference group theory. This theory, developed in the 1950s by social psychologists, states that people identify with all sorts of groups. These reference groups can be attracting or repelling. The individual can develop a strong or a weak identification with the group, and this identification can either be positive or negative. Political parties can be thought of as reference groups. Given this psychological foundation, party ID should be distinguished from voting behavior, otherwise we would miss the essential distinction between an attitude and the behavior it causes. The distinction between party ID and voting behavior allows us to examine under which circumstances individuals defect from their usual partisanship by voting for a different party.

Since the publication of The American Voter, the literature on party ID has focused on two distinct but interrelated concerns. The first one questions the exceptional stability that Campbell et al. attribute to party ID. Is every sudden shift in party ID attributable to exceptional periods of partisan realignment? The second concern somehow hinges on the first one, and questions the exogeneity of party ID. If party ID is unstable, can we explain the variation by other political or economic variables? Which variables may explain shifts in party ID, at the individual as well as the aggregate level? 
Four years after the publication of the American Voter, the stability of party ID was somewhat overtaken by events. In the 1964 presidential election, aggregate party ID changed more dramatically than any time before or after (Dreyer 1973). The mere fact of changing party ID does not conflict with the views expressed in "the American Voter". However, the views of the Michigan Four could only remain persuasive if these changes were occurring only as part of a major party realignment, and not as part of the normal ebb and flow of politics.

At the time "the American Voter" was published, the concept of party ID and the fundamental role attributed to it by the Michigan Four was favorably received by the scientific community. For more than two decades, it provided the basic structure for most studies of voting. However, from the 1970s onwards, the emotional, non-rational nature of party ID, its stability and its primordial place in models of political behavior became matters of dispute. Most of the critique was rooted in rational choice theory (Downs 1957).

In the 1970s and 1980s, several scholars questioned whether party ID is really exogenous, i.e. whether party ID is unaffected by the occurrences of day-to-day politics. From then on, two competing views of party ID divided the scientific community. The first view considers party ID as an unmoved mover, the key variable that explains political behavior and attitudes but cannot be explained by them. In the second view, party ID is shaping behaviors, attitudes and perceptions, and at the same time these factors are affecting party ID.

Until the 1970s, most studies that related different political variables to each other implicitly presumed a certain order of causality. Jackson (1975) published the first analysis of voting behavior based upon an explicit non-recursive causal model, i.e. he simultaneously related the endogenous variables of people's evaluations of the parties' positions, their issue preferences and the strength of their party ID to one another. Using data from the 1964 presidential election, he found evidence in support of the hypothesis that party ID is to a large extent the result of issue proximities, rather than social characteristics. He concluded that "party IDs are highly influenced by people's evaluations of what policies each party advocates relative to their own preferences," 
and that "party affiliations have little direct influence on the voting decision except for people who see little or no difference between the parties' issue positions”. This was a major challenge to the theoretical status of party ID in the Michigan model.

Four years later, two papers examining the causal links between overall candidate evaluations (measured by the "feeling thermometer" scores ${ }^{3}$ ), party ID and issue proximities, and evaluations of candidates' personal qualities (as measured by spontaneous responses to open-ended items about candidate likes and dislikes) were published in the same issue of the American Political Science Review. Surprisingly, Page and Jones (1979) and Marcus and Converse (1979) reached different, if not contradictory conclusions. Markus and Converse (1979) reported that party ID had a strong influence on evaluations of the candidates' personalities. Page and Jones (1979) treated party ID and personality evaluations as unrelated, except insofar as personality evaluations (which are exogenous in their model, i.e., not influenced by party ID, voting history, income etc.) influenced overall candidate evaluations, which in turn influenced party attachments (Bartels, 2008). Markus and Converse (1979) concluded that "while partisan predispositions are unlikely to dominate the process completely at given stages where the candidates are being assessed, these loyalties appear to make repeated inputs of substantial magnitude throughout the process." Page and Jones (1979, 1088), by contrast, concluded that "the effect of partisanship on the vote varies considerably across elections, depending largely upon the nature of the candidate pairings and the extent to which current policy issues conflict or coincide with established party cleavages." They added that "when party loyalties do enter in, they do not function purely as fixed determinants of the vote; those loyalties can themselves be affected by attitudes toward the current candidates. Even short of major realignments, party affiliations are effects as well as causes in the electoral process” (Page and Jones 1979).

Franklin and Jackson (1983) argued that party identifications are more than the results of a set of early socializing experiences, possibly reinforced by subsequent social and political activity.

\footnotetext{
${ }^{3}$ In thermometer questions, respondents are asked: “do you have a favorable (warm) or unfavorable (cold) feeling towards this politician/party? (scale from 0 to 100).
} 
They are a person's accumulated evaluations from previous elections and are dependent upon the events and the actions of political leaders during these elections and during subsequent terms in office. They concluded that changes in party ID originate in shifts in the perceived party proximities to their own preferences.

The most prominent scholar among the critics of the Michigan Four is Morris Fiorina. Whereas the Michigan Four spoke of a stable, affective and identity-based party ID of almost exogenous status, Fiorina saw a potentially volatile, rational, policy-based party ID with a clear endogenous position in the funnel of causality. To Fiorina, party ID was not primarily an identity. Instead, it was a weighted average of past evaluations of the parties - a "running tally" of reaction to past political and economic happenings (Fiorina, 1981). In Fiorina's view, people come to think of themselves as belonging to a particular party from events of childhood and early adolescence, but each subsequent political event can move the tally one way or the other.

Achen (2002) explained party ID as the result of a continuous Bayesian updating process with respect to expected future benefits from a party and its candidates. Starting from a very simple rational choice model for parental socialization of children's party ID, he finds that children will have adult partisan positions correlated with that of their parents and that these positions are related to benefits received from political parties.

As noted above, the huge swings in aggregate party ID following the 1964 presidential election casted some doubts on the stability of party ID. However, it was only in 1989 that the aggregate movements in party ID were examined more closely. MacKuen, Erikson and Stimson (1989) presented evidence that macropartisanship fluctuates in response to changes in consumer confidence and presidential approval. Their analysis was replicated by Green et al. (1998), who found considerably less evidence of partisan fluctuation. They found that short-term effects (consumer sentiment and presidential approval) have only half of the effect that MacKuen et al. 
suggested. They concluded that the earlier view of realignment remained persuasive: partisanship is generally stable, except for occasional significant realignments.

\section{Party ID and Economic Assessments}

A robust finding in the literature is that partisans evaluate the economy more positively when their party is holding office, and more negatively if the government is controlled by an opposing party (e.g. Bartels 2000, 2002, 2006; Conover, Feldman, and Knight 1986, 1987; Evans and Andersen 2006; Gerber and Huber, 2010; Lewis-Beck et al. 2008; Wilcox and Wlezien 1996). Many scholars have been intrigued by this longstanding observation, and have come up with several plausible explanations why this correlation between partisan attachments and economic assessments may occur.

We will discuss five different explanations. The first three are in line with the model developed by Campbell et al. (1960), i.e. they hinge on the fact that partisanship, as an "unmoved mover", affects the individual's perception of the state of the economy. The fourth explanation addresses the question of endogenous partisanship, and reverses the order of causality in the relationship between partisanship and the evaluation of the economy. The fifth explanation argues that the use of divergent criteria to evaluate the economy can affect party ID (People who care a lot about healthy public finances are more likely to identify with the Republicans.), but can also be affected by it (Republicans are more likely to attach great importance to healthy public finances.).

A first explanation stems from the desire of respondents to appear consistent. This phenomenon, sometimes labeled as "partisan cheerleading” (Gerber and Huber, 2010), insinuates that survey 
respondents who identify with a party are not answering sincerely when they are asked about their perception of the economy.

It has often been pointed out that Western society contains strong social pressures toward appearing consistent. Therefore, it should not be surprising that when people are asked about their political preferences and their perception of the economic situation in the same survey, some of the respondents will (intentionally or not) try to respond consistently. Sears and Lau (1983) find evidence of such survey-induced consistency between political preferences and respondents' personal financial situation. They argue that the often-reported correlation between economic assessments and political preferences may be due to one of the following artifacts, depending on the order in which the survey questions were posed: political preferences may have been personalized by assessing them immediately after the respondent's own economic situation has been made salient, or perceptions of personal economic situations may have been politicized by assessing them immediately after major political preferences have been made salient. Even though Sears and Lau focus on political preferences in general, we could argue that this caveat holds true $a$ fortiori when respondents are asked about their party ID.

Palmer and Duch (2001) demonstrate that economic evaluations are subject to the "priming" effects associated with partisanship questions. As expected, priming effects are most likely to shape the responses of individuals with “inconsistent” political and economic attitudes. As others have argued (e.g., Lau et al. 1990), these priming effects have serious implications for economic voting models because the correlations between economic evaluations and political preferences are artificially inflated by question placement. Accordingly, economic evaluation questions should ideally precede questions about partisan preferences.

But even if respondents are sincere in surveys that gauge their evaluation of the economy, partisan leanings can affect their judgment in more subtle ways. The second explanation for the observed correlation between economic assessments and party ID stems from a partisan bias in 
the way people gather information. When people (only) read newspapers and watch TV channels with an ideological basis similar to their own, they may have a biased view on the state of the economy.

Duch, Palmer and Anderson (2000) find that there is an endogenous relationship between partisanship and perceptions of the national economy. Citizens' views of the economy are biased by their own partisan preconceptions, perhaps limiting the potential for citizens to vote rationally based on this information.

Using a sample of 140 United States (US) newspapers published over the period 1996 - 2006, Larcinese, Puglisi and Snyder (2007) investigate whether there is any significant correlation between the endorsement policy of newspapers, and the differential coverage of bad/good economic news as a function of the president's political affiliation. They find evidence that newspapers with a pro-Democratic endorsement pattern systematically give more coverage to high unemployment when the incumbent president is a Republican than when the president is Democratic, compared to newspapers with pro-Republican endorsement pattern. They also check whether this result is driven by demand factors (i.e. the partisanship of the readers), or supply factors, and conclude that "agenda bias in economic news seems more connected with the partisan position of editors, i.e. a supply factor, rather than with the ideological tastes of readers”.

A third explanation attributes the observed correlation to selective perception of the respondents. Even if all individuals are exposed to the same information, partisan attachments may influence the way in which this information is processed. A study by Lodge and Hamill (1986) shows the effects of party ID on information processing. When presented with statements by a fictional congressional leader, people who identify with one of the two main American parties were more able to correctly categorize statements as being Republican or Democrat than people who do not identify with a party. Furthermore, party identifiers were better able to recall statements that were consistent with the party than those that were inconsistent. Party identifiers also 
"systematically distort the congressman's stance on the issue by imposing more partisan consistence on his policy positions than was actually present in the campaign message" (Lodge and Hamill, 1986, p.518). Rahn (1993) examined under which circumstances people abandon their use of party stereotypes when evaluating a candidate. In an experiment, she tested how policy information that was incongruent with a candidate's party affiliation changed people's evaluation of that candidate. She concluded that voters neglect policy information when they evaluate a candidate, 'they use label rather than policy attributes in drawing inferences, and they are perceptually less responsive to inconsistent information”.

A fourth explanation contests the exogeneity that Campbell et al. ascribed to party ID, stating that partisan attachments shift in response to an individual's perceptions of economic circumstances. The possibility of endogenous partisanship was first expressed by Morris Fiorina, in his seminal paper "Economic Retrospective Voting in American National Elections” (1981). Fiorina argues that party ID is really a "running tally" of recent political evaluations (cfr. supra). MacKuen, Erikson and Stimson (1989) show that these movements can also be observed at the aggregate level. They present evidence that the aggregate balance of party identifiers between the two main US parties (macropartisanship) shifts in response to changes in presidential approval and consumer confidence. Luyten and Crombez (2012) investigate whether this relationship also holds in Germany. They conclude that the relative size of the partisan base of the main German parties is indeed affected by consumer confidence and government approval. However, the strength of both effects differs among the parties.

A final explanation for the observed correlation between evaluations of the economy and party ID stems from the fact that people use different criteria to judge the economy's health. These criteria in turn, may be correlated with political preferences and party ID (Gerber and Green, 1999). Complications then arise if one wants to examine the relationship between party ID and an aggregate measure of subjective economic wellbeing, such as most indexes of consumer confidence. 


\section{Party ID in Europe}

The concept of party ID was received with mixed feelings in Europe. In Scandinavia, the scientific community responded moderately positive, while scholars on the rest of the continent were more skeptical (Holmberg, 2007). Some casted doubt on the existence of this attitude in Europe, where political identities are much more rooted in socio-economic or religious affiliations (e.g. Thomassen, 1976; Kaase, 1976). Others doubted whether this concept is meaningful in Europe, where the political system in gave rise to a party landscape that is less stable than that of the US (e.g. Butler and Stokes, 1969).

\section{The Existence of Party ID in Europe}

It should not be a surprise that the concept of party ID and its wide applicability in American political science is not readily transposable to European politics. American voters are confronted with two parties, and have to make many electoral decisions on candidates. In most European countries, citizens have to choose between a larger number of parties. Some of these parties have existed for a long time, have acquired a governing record in several coalitions and have developed an extensive supporting organizational network. Others are small single-issue parties that appeared on the political scene more recently. Evidently, these characteristics affect a party's ability to attract and retain loyalties. Furthermore, many European countries have a system of proportional representation. This often induces voters to choose between parties rather than candidates. As such, if a citizen who remained loyal to a specific party for a long time suddenly casts a ballot for a different party, it should be interpreted as a rejection of the former party rather than a rejection of a specific candidate within this party. Therefore, the distinction 
between vote intention and party ID is probably less clear in countries with a system of proportional representation (Butler and Stokes, 1969).

Furthermore, in many European countries the composition of the parties in the political landscape is constantly changing. Some parties merge, others disappear, still others change their names, etc. Such changes in the partisan landscape may hinder the development of long-lasting ties between citizens and political parties.

\section{Is Party ID a Meaningful Concept in Multiparty Systems?}

A second critique stems from the fact that many European parties are just one aspect, or even a product, of a broader social identity. The social affiliation of voters is much more important in European politics than in US politics. The nature of this social affiliation and its relationship with political identification have been the subject of intense study throughout the past fifty years.

In their classic book "Party Systems and Voter Alignments" (1967), Seymour Martin Lipset and Stein Rokkan argue that parties have embedded themselves along fundamental lines of conflict, or cleavages, such as the conflict between the center and the periphery of a state, the conflict between labor and capital and the conflict between church and state. These cleavages have been 'frozen', i.e. they are still present in modern day politics, even though the original conflicts have been resolved to a large extent.

The manifestation of these conflicts is by no means restricted to the political arena. In some countries, such as Belgium, the Netherlands and Austria, they induced a 'pillarization' of society. In these countries, society was (and in some areas, still is) segregated into several segments or 'pillars' according to religion and ideology. Each pillar consists of a number of social institutions such as trade unions, political parties, newspapers and even sports clubs. 
The precise nature of this social identification lies outside the scope of this article. However, it is important to realize that social identification may be more complicated outside the US, which necessitates some modifications in the way we assess electoral stability and the impact of party ID. Shively (1972), for example, demonstrates that once we aggregate the voting shares of parties with similar social clienteles, electoral stability increases significantly. Of course, it remains difficult to operationalize such a social identification. In the next section, we discuss which problems arise because of the complex nature of European political affiliations, and we investigate whether propensity-to-vote-for-a-party data can overcome these complications.

\section{The Measurement of Party ID in Europe: Can PTV Data Cast Light on European Partisanship?}

The measurement of party ID in multiparty systems is not as straightforward as in two-party systems. First of all, it is far from unthinkable that voters in multiparty systems identify with more than one political party. Secondly, some authors argue that in many countries negative identifications are as important as positive ones. Finally, we assess whether these obstacles can be circumvented by applying an operationalization of party ID based on PTV questions rather than the classical survey question from e.g. the Gallup surveys. PTV data are based on survey questions that ask respondents how likely it is that they will ever vote for a specific party. These data allow for multiple identities, as well as positive or negative identities.

\section{The Problem of Multiple Identities}

When we apply the concept of party ID in multiparty systems, a major problem stems from the fact that people may identify with multiple parties. Van der Eijk and Niemoller (1983) examined the possibility of multiple party identities in the Netherlands. They note that approximately one third of all respondents, and approximately half of all identifiers, reported that they identified with more than one political party. They conclude that 'the assumption that voters identify with 
only one party (if they do so at all) turns out to be false when subjected to an empirical test in the Netherlands’ (p338).

Schmitt (2002) used a question wording that did not explicitly ask about identifying with more than one party but rather left it to the respondent to sum up the parties he or she identified with. He found that an average of 10 percent of respondents - in the fourteen European countries studied - identified with more than one party. Therefore, he argued that "multiple party identifications are indeed a relevant aspect of partisanship. Noteworthy proportions of national electorates identify with more than one political party”.

Weisberg (1999) explains multiple party identities as a logical result of a political landscape with a large number of parties. In a multiparty system, he states, it is very likely that a number of parties are not very dissimilar to each other and so 'such multiple identification should not be surprising' (Weisberg 1999, p727). Weisberg notes, for example, that people who identify with one of the Dutch Calvinist parties may very well have also identified with another Calvinist party. He concludes that "there is enough variation in party systems around the world to expect many variations like this in particular countries”.

\section{Positive as well as Negative Identities}

Besides the fact that the Michigan operationalization of party ID does not allow for multiple identities, some scholars have also criticized it on its inability to capture negative identities. Despite the emphasis in the original definition (cfr. reference group theory) on both the negative/repellent and positive/attractive components of party ID, almost all analyses that use the concept of party ID have focused on positive identification only. Maggiotto and Pierson (1977) argue that identification should incorporate attitudes to the opposition party as well as to the favored party. The addition of partisan hostility, the authors argue, increases our understanding of why certain voters are more likely than others to defect from their favored party. 
Richardson (1991) expresses the same critique, stating that it is of particular importance in the European context. In Europe, he argues, “partisanship may be more appropriately considered a choice of a party within the context of the alternatives existing within a particular party system at a particular time' and that, therefore, negative 'hostility to parties other than favored ones may be as important behaviorally as positive ties to liked parties' (1991). Richardson argues that because European party systems arose out of cleavage politics - deep divisions along religious, class or ethnic lines (Lipset and Rokkan 1967, cfr. supra) - 'interparty hostility may be a common component of European partisanship alongside positive feelings toward preferred parties'.

\section{The Operationalisation of Party ID through PTV}

Lachat (2006) uses electoral utility to evaluate two models of party ID, i.e. the Michigan model and the revisionist model. Electoral utility stems from "models of electoral choice" that assume that citizens' vote choices are the result of a process consisting of two stages. In the first stage, the citizen assigns a level of utility to each party/candidate. In the second stage, the voter casts his ballot following a decision rule. PTV questions are often used as an operationalization of electoral utility. In the classical (Michigan school) model, party ID is an enduring commitment which shapes attitudes towards political objects and voting choices. The revisionist model argues that party ID is more responsive to new information and to short-term political forces than expected by the classical model.

Following the logic of the revisionist model, the relationship between voters' political attitudes (often measured on two scales: left-right and pro-contra European integration) and their electoral utilities should be strong. Furthermore, electoral utility should not be affected by party ID. The reason for this is that a voter's party ID is the result (not the cause) of the high level of electoral utility he derives from a particular party over a long period of time. Electoral utility, in turn, is the result of other variables, such as the distances between a voter and a party on the two scales mentioned above. In the classical model, by contrast, party ID should have a direct impact on electoral utilities, and these should be only weakly related to voters' political attitudes. In this 
line of thinking, voters get electoral utility from a particular party merely because they identify with it. In the classical model, party ID is such a strong force that voting for the party closest to a voter's position on the two scales, for example, will not (necessarily) maximize the voter's electoral utility if he identifies with another party. The results of Lachat's empirical models are mixed. They offer partial support for both conceptions of party ID.

\section{Suggestions for Future Research}

Compared to the traditional survey questions on which party ID data are based, PTV scores offer us a broader and much clearer picture of the partisan preferences of European respondents. This allows us to investigate some interesting questions about the relationship between economic variables such as consumer confidence and the partisanship of the citizens. As respondents can express multiple identities, it makes sense to look for the characteristics shared by their favorite parties. For example, some people may 'identify' with several new anti-establishment-parties at the same time. Others may identify with a number of parties that have in common that they have not (yet) agreed to a compromise in a coalition government. It would take us rather far from the Michigan Four to label such a relationship as an identification. It is undoubtedly not a 'stable sense of personal attachment [...] towards a party' (Campbell et al., 1960), but in the changing realm of European politics where new parties emerge and disappear and traditional parties are in many cases in decline, it is not unthinkable that some people 'identify' with a number of parties that share an attitude in the political arena rather than identify with a particular party. Furthermore, it seems likely that such an identification is related to the voters' assessment of the economy.

\section{Conclusions}

In addition to presenting a literature review the contribution of this paper is twofold. First of all, we provide an outline of the complications that arise if one wants to assess the impact of 
economic variables on party ID in Europe. Second, we assess the potential of Probability-ToVote data to overcome these complications.

The observed correlation between party ID and economic variables in the US is still in search of a (unified) theory. Scholars have come up with a wide variety of possible explanations. These explanations are often contradictory, and empirical research has not yet produced a clear picture of the causal flows between party ID, consumer sentiment, economic growth etc. The primary cause of disagreement concerns the place of party ID in the funnel of causality. The original view on party ID, as expressed by Campbell, Converse, Miller and Stokes, considers party ID as an unmoved mover, i.e., a variable that affects other political attitudes and behavior, but cannot be affected by them. Even though this view still has many adherents, several authors contested it, arguing that party ID is endogenous. In their view, there is at least some reciprocal causation between party ID and other variables such as consumer confidence or issue proximity. As the discussion is not yet settled, and party ID remains one of the strongest determinants of the vote choice, it seems unlikely that the scholarly attention towards this subject will soon fade out.

Many scholars have tried to transpose the concept of party ID outside the US context. The transposition of this concept to European multiparty systems has brought a number of complications to attention. In multiparty systems, individuals may identify with more than one party. Furthermore, they may have positive as well as negative identifications with political parties. The standard survey question on party ID, however, does not allow for multiple or negative identities. PTV-questions, that gauge respondents' intention to ever vote for a particular party, may offer a way to circumvent these complications. However, the relationship between PTV scores and economic variables remains largely unexplored. 


\section{References}

Achen, C., 1975. "Parental socialization and rational party identification”. Political Behavior 24. 2. 151-170.

Bartels, L., 2000, “Partisanship and Voting Behavior, 1952-1996.” American Journal of Political Science 44(1): 35-50.

Bartels, L., 2002, “Beyond the Running Tally: Partisan Bias in Political Perceptions.” Political Behavior 24(2): 117-50.

Bartels, L., 2006, “Priming and Persuasion in Presidential Campaigns.” In Capturing Campaign Effects, ed. Henry E. Brady and Richard Johnston. Ann Arbor: University of Michigan Press, 78-112.

Bartels, L., 2008, “The study of electoral behavior”. in Leighley, J., “The Oxford handbook of American elections and political behavior”. Oxford University Press.

Budge, I., Crewe, I. and Farlie, D. (eds), 1976, “Party Identification and Beyond.” New York: Wiley.

Butler, D., and Stokes, D., 1969. "Political Change in Britain: Forces Shaping Electoral Choice”. New York: St. Martin’s Press.

Campbell, A., Converse, P. , Miller, W. and Stokes, D., 1960. “The American Voter”. New York: Wiley.

Conover, P., Feldman, S.and Knight, K., 1986, “Judging Inflation and Unemployment: The Origins of Retrospective Evaluations.” Journal of Politics 48(3): 565-88. 
Dalton, R and Wattenberg, M. (eds), 2000, "Parties without Partisans: Political Change in Advanced Industrial Democracies”. Oxford: Oxford University Press.

Dalton, R. and Weldon, S., 2007. "Partisanship and Party System Institutionalization” Party Politics. Vol 13 no. 2, 179-196.

Downs, Anthony (1957). “An Economic Theory of Democracy”. New York: Harper and Row.

Dreyer, E., 1973 “Change and Stability in Party Identifications”. The Journal of Politics, Vol 35, Issue 03, pp 712-722.

Duch, R., Palmer, H. and Anderson, J., 2000. "Heterogeneity in Perceptions of National Economic Conditions.” American Journal of Political Science, 44:635-52.

Evans, G. and Andersen, R., 2006. “The Political Conditioning of Economic Perceptions.” Journal of Politics 68(1): 194-207.

Fiorina, M., 1981. “Retrospective Voting in American National Elections”. New Haven: Yale University Press.

Franklin, C. and Jackson, J., 1983. “The Dynamics of Party Identification”. American Political Science Review 77:957-73.

Garry, J., 2007. "Making party identification more versatile: Operationalising the concept for the multiparty setting”. Electoral Studies. 26. no.2.: 346-358. 
Gerber, A. and Huber, G., 2010, "Partisanship, political control and economic assessments”. American Journal of Political Science, Vol. 54 No. 1, pp 153-173.

Green, D. and Palmquist, B., 1994. "How stable is party identification?”. Political Behavior , 16, 437-466.

Green, D., Palmquist, B. and Schickler, E. 1998., "Macropartisanship: A Replication and critique”. American Political Science Review 93(December):883-99.

Holmberg, S, 1994, "Party Identification Compared Across the Atlantic", in Jennings, M. and Mann, T (eds), Elections at Home and Abroad. Ann Arbor, MI: University of Michigan Press.

Holmberg, S., 2007, “Partisanship reconsidered”. in Dalton, R. and Klingeman, H. (eds.). The Oxford handbook of political behavior., Oxford Univeristy Press.

Jackson, J. 1975. "Issues, Party Choices, and Presidential Votes." American Journal of Political Science 19: 161-185.

Kaase, M., 1976. "Party Identification and Voting Behavior in the West German Election of 1969”. in Budge, I., Crewe, I. and Farlie, D. ed. 1976. Party Identification and Beyond. New York: John Wiley \& Sons.

Lachat, 2006. "Party identification, electoral utilities, and voting choice", Conference paper ECPR, Nicosia 2006.

Larcinese, V., Puglisi, R. and Snyder, J., 2007. "Partisan Bias in Economic News: Evidence on the Agenda-Setting Behavior of U.S. Newspapers”. Journal of Public Economics, Elsevier, vol. 95(9-10), pages 1178-1189. 
Lewis-Beck, M., Jacoby, W., Norpoth, H. and Weisberg, H., 2008, “The American Voter Revisited.”Ann Arbor: University of Michigan Press.

Lipset, Seymour M. and Stein Rokkan. 1967. “Cleavage structures, party systems and voter alignments: an introduction.” in Lipset, Seymour M. and Stein Rokkan (eds) Party Systems and Voter Alignments: Cross National Perspectives. New York: The Free Press.

Lodge, Milton, and Ruth Hamill. 1986. “A Partisan Schema for Political Information Processing.” American Political Science Review 80:505-519.

Luyten, A. and Crombez, C., 2012, “Aggregate partisanship in Germany: The effects of consumer confidence and government approval”. MSI Working Paper.

MacKuen, M., Erikson,R. and Stimson, J., 1989. „Macropartisanship”. American Political Science Review 83: 1125-42.

Maggiotto, Michael and James Pierson. 1977. "Partisan identification and electoral choice: the hostility hypothesis.” American Journal of Political Science 21:745-767.

Marcus, Gregory B., and Philip E. Converse. 1979. "A Dynamic Simultaneous Equation Model of Electoral Choice." American Political Science Review 73: 1055-1070.

Miller, W., 1991. Party identification, realignment and party voting: Back to the basics. American Political Science Review, 85: 557-568.

Miller, Warren E. and J. Merrill Shanks (1996). The New American Voter. Cambridge: Harvard University Press. 
Page, Benjamin I. and Calvin C. Jones (1979). "Reciprocal Effects of Policy Preferences, Party Loyalties and the Vote”, American Political Science Review 73(4): 1071-1089.

Palmer, H. and Duch, R., 2001. "Do Surveys Provide Representative or Whimsical Assessments of the Economy?" Political Analysis 9(1), 58-77.

Rahn, W., 1993. "The Role of Partisan Stereotypes in Information Processing about Political Candidates”. American Journal of Political Science 37:472-496.

Richardson, Bradley. 1991. “European Party Loyalties Revisited”. American Political Science Review 85:751-775.

Schmitt, Hermann. 2002. "Multiple Party Identifications.” Paper prepared for the conference of the Comparative Study of Electoral Systems (CSES) at the WZB in Berlin, February 21-24 2002.

Sears, D. and Lau, R., 1983. "Inducing apparently self-interested political preferences”. American Journal of Political Science 27: 223-252.

Shively, W., 1972. "Party identification, party choice, and voting stability: the Weimar case". American Political Science Review 66 (4), 1203-1225.

Thomassen, J., 1976. "Party identification as a cross-national concept: its meaning in the Netherlands. In: Budge, I., Crewe, I., Farlie, D. (Eds.), "Party Identification and Beyond: Representations of Voting and Party Competition”. John Wiley \& Sons, London, pp. $63 e 79$.

Van der Eijk, C. and Niemoller, C., 1983. "Electoral Change in the Netherlands”. Amsterdam: CT Press. 
Weisberg, H., 1999. “A multidimensional conceptualization of party identification”, Political Behavior 2, 33-60.

Wilcox, N. and Wlezien, C., 1996. "The Contamination of Responses to Survey Items: Economic Perceptions and Political Judgments.” Political Analysis 5(1):181-213. 